\title{
THE INTERRELATIONS BETWEEN THE CENTRAL AND LOCAL BUDGETS IN ROMANIA - PROBLEMS AND POSSIBLE SOLUTIONS
}

\author{
Florin Oprea ${ }^{1}$
}

\begin{abstract}
By integrating public budgets and their interrelationships, the public budgetary system must meet, through its actual configuration, some rationality requirements that should ensure the necessary support in order for it to contribute to the overall economic and social development. In these conditions, a universal structuring model of public budgetary systems in excluded on principle, but common foundation elements serving their functionality may and must be identified. On this premise, our article aims at highlighting, based on qualitative and quantitative research, the design and functioning method of the interrelationships between the state budget and local budgets, pointing out their implications for the functionality of the budgetary system and for the "soundness" of public finances, proposing corresponding improvement solutions.
\end{abstract}

Key words: public budgetary systems, intergovernmental fiscal relations, local financial autonomy

JEL codes: $H 7$

\section{Introduction}

Public budgetary systems are structured under the impact of two categories of factors: the state structure, namely the territorial organization of public power, on the one hand, and the public needs to be managed, on the other. In these conditions, a universally applicable structuring model of the public budgetary systems cannot be put forward nor is it necessary, because the budgetary system must meet, through the components it incorporates and their interrelationships, some dynamic social requirements, which translates into the need to preserve a certain flexibility in this system. It is without doubt that, in fact, the current economic and financial crisis is mainly related to public budgets, if we take into account the delimitation of their scope, the material foundation of income and expense indicators and the configuration and materialization of the interrelationships between public budgets. In these conditions, identifying faulty approaches, namely the optimum structuring versions of public budgets and their interrelationships, becomes not only useful, but also necessary for counteracting negative economic and social effects of current economic developments, by reconsidering Romania's public budgetary system, in order to increase its functionality.

\section{Literature Review}

The subject matter of public budgetary system structuring and the interrelationships between their components is a topical issue, often leading to controversies of substance, both in the domestic literature and in the foreign literature in the field. Although it may seem that the theoretical bases of the interrelationships between public budgets were completely cleared up in the context of the "fiscal federalism" issue (Musgrave, 1959 and Oates, 1999), applying "the general rules" means that they are in a way singularized, context in which, though, many system dysfunctions may occur. These potential negative effects are first a result of the fact that the principles under discussion are applicable or applied differently in each state, with differences noted especially between the unitary and the federal states, as they are not able to represent a "universal recipe". Although

\footnotetext{
1 “Al. I. Cuza” University of Iaşi, Carol I Bd., no. 11, foprea@uaic.ro
} 
"universalization" of the set of principles considered to be the content of fiscal federalism (in the sense of them being universally recognized) may be found in the related literature and in practice, each of these principles involves a certain degree of relativity, in the sense that it has to be connected to the requirements and the actual reality in each state. Moreover, one and the same principle may be interpreted and applied more or less nuanced, thus leading to a particular way of promoting fiscal decentralization. For example, the subsidiarity principle applied to the mobilization of budget revenues or the principle of assuring a certain level of local autonomy involve judgements that are subjective in their nature, regarding the extent and the beneficial effects of allowing competences to the local government level, thus leading to different manners of applying subsidiarity and to different interpretations of the degree of local autonomy. On the other hand, the theoretical foundations of fiscal federalism and its applicability are still submitted to observations and reconsiderations, sometimes even by those who put them forward, "a second generation" of fiscal federalism being invoked.

Administrative decentralization, as a process of transferring certain competences from the central level to sub-national administrations, creates the premises for making public financial relationships more effective (Văcărel, 2006, Moşteanu, 2008) and for increasing the positive effects on local development by transferring responsibility to local actors (Onofrei, 2007). However, this is only possible as long as the delimitation of the resources and expenses of the two categories of public budgets involved is very clear, stable and in accordance with the rationality criteria regarding the capacity of local administrations to undertake certain activities (Shah, 2008, McLure, MartinezVazquez, 2000). Without them, the public budgetary system may experience substantial dysfunctions, sometimes even reaching paradoxical situations (while sums of money, partially originating from loans, are transferred from the state budget to balance local budgets, the latter have budget surpluses).

\section{Research Methodology}

In order to assess the functionality of Romania's public budgetary system from the point of view of the interrelationships between the state budget and local budgets, our study first proposes a qualitative analysis, highlighting their main transformations and organizing their main characteristics and the effects generated at the level of the efficiency of public financial relationships. At the same time, in order to identify and interpret the concrete results of the design and manifestation of public budgets (both state and local) and of their interrelationships in Romania, we propose a quantitative analysis based on the income, expenses and transfers between them, which should highlight the performances of each public budget component and of the overall system. Based on this, we will point out the main sources of dysfunction for Romania's public budgetary system, also proposing solutions to remedy them.

\section{Theoretical Foundations of the Interrelationships between the State Budget and Local Budgets}

The public budgetary system structuring is closely related to the form of the public power. The organization of these systems, having the central budget and local budgets as main pillars, based on the state structure, is organically linked, in its turn, to differentiating public needs as "national" or "local", the former reflected in the state budget and the latter in the local budgets.

The state budget (of the central administration), due to its specific content, is a first level component of the public budgetary system, having a privileged position among the other functional instruments of public financial management. Its special position comes, on the one hand, from the fact that the state budget (central budgets) finances the most important actions, considered to be of national social interest (e.g.: national defense, diplomatic relationships, programmes designed to promote the country's image, research and development, etc.). On the other hand, the considerable importance of the central budget as opposed to the other components of the public budgetary system 
may be observed in the fact that, in conditions considered to be normal, budgetary incomes having as a jurisdiction source the entire state territory are mobilized to this budget, as they are more substantial, but many of them also more sensitive to the economic circumstances (tax on the profit of economic entities, value-added tax, excises, etc.). These incomes actually come from tax levies which essentially have, beside their traditional financial function (of ensuring state budgetary resources), a regulation/ stabilization function which is not always achieved with the same intensity in the case of levies attributed to other public budgets (e.g.: property taxes mobilized to local budgets). In other words, tax levies attributed to central budgets are, traditionally, the most important leverages of the financial (tax and budgetary) policy of the state, having the ability to mediate influencing (inhibiting or stimulating) certain economic and social processes in the manner deemed desirable at a certain moment by the public authorities.

The global effect of the possibility to use these levies in this manner leads to the state budget being qualified as an active influencing instrument of economic and social life, as it is considered, in various circumstances, as either "the pathogen" or the "medicine" that determines the soundness of the public finances of a state and the rhythm or the level of its economic and social development.

In their turn, local budgets are characterized in the public finance theory (Văcărel, 2006) by assimilation with the meanings given to the state budget, as they are associated, as a rule, with the concept of local autonomy, which means that local authorities manage, on their own responsibility and on behalf of the local community, an important part of public tasks. Recognizing that local authorities have competences different from those of public central authorities is based, in its turn, on differentiating specific (public) social interest categories, among which some may be considered national (being felt the same way by all the members of the national community and satisfied without differences, as is the case of national defense or justice), and others may be considered local, their perception and the concrete manner in which they are satisfied being different from one community to another.

The heterogeneity of local communities and of the specific needs of their members is then related to the degree to which central authorities know the preferences (in what concerns public services) as opposed to local authorities. It is normal, from this point of view, that the needs (interests) of the members of sub-national communities, and their preference concerning the manner in which they are satisfied, should be better known at local level. As a result, we note that, differentiating public interests in "national" and "local" interests and individualizing, on this basis, central budgets and local budgets, creates an adequate support to make public financial relationships more efficient. However, it must be noted that the simple fact of establishing local budgets as complementary components of the central budget in the public budgetary system is nothing but a premise for making public financial relationships more efficient, which may lead, in the case of confusing delimitations or of inadequately designing and promoting the interrelationships between these components, to a contrary result. Also, another important premise which supports the achievement of a higher degree of efficiency is the fact that local authorities may know better (than central authorities could) both the financial (fiscal) potential and the needs regarding the expenses to be covered. At last, another important premise of making public financial relationships more efficient is the fact that the distinctive organization of the local public financial relationships system (in autonomy conditions, reflected in and supported by local budgets) would allow relieving central finances of certain expenses, would decrease the number and extent of the flows between the two major components of the public financial system (central and local finances) and would create a basis for a more efficient control of establishing and using public financial funds (Văcărel, 2006). Admitting the idea that providing local utility services is more efficient if done directly by local authorities, the issue of differentiating the scope of these utilities comes up, which, in essence, means extending local (administrative and financial) autonomy. In this regard, there may be no rule, no general (universal) model of recognizing and supporting local autonomy, each state having different practices, based on elements of tradition, circumstance, law, ideology, politics, etc. 
However, needs such as defense, justice, national security, foreign relations, macro-economic stabilization or social welfare are commonly considered strategic needs and are managed by central authorities, being reflected in and financed by central budgets. On the other hand, needs such as the ones regarding local public order, roads, public lighting, local transportation, sanitation, schools, etc. are often transferred to the competence of local authorities, being included in and financed by local budgets. In both hypostases, it is also possible to find, in different ratios, the shared management, between the two administrative levels, of these activities.

Characteristics of the Design and Manifestation of the Interrelationships between the State Budget and Local Budgets in Romania

In the context of passing to the democratic government system after 1990, Romania initiated extensive administrative reforms, with substantial budgetary implications. In these conditions, a more consistent restructuring direction in the Romanian public budgetary system was and still is the reinforcement of local budgets as essential instruments for ensuring local administrative and financial autonomy.

With this stated purpose, authorities in Romania promoted, by means of various normative documents, measures meant to reinforce the condition of local budgets and allow them to highlight their specific possibilities, but the process took place much too slowly. Thus, although administrative decentralization and local autonomy as essential principles of the organization and operation of the local public administration had been regulated ever since 1991 by way of the Constitution, the actual process was initiated in 1993, with little reflection at the budgetary level.

Accepting decentralization as a "megatrend" with positive effects at the level of making public financial relationship more efficient and providing local public goods, political groups that alternately took power promoted substantial reforms, by which many of the competences previously exercised by the central power were transferred to the local level. As a result, the effect of this process meant a decrease in the specific weight in the budgetary system of the state budget, in favour of the local budgets, tendencies graphically represented in the following figure:

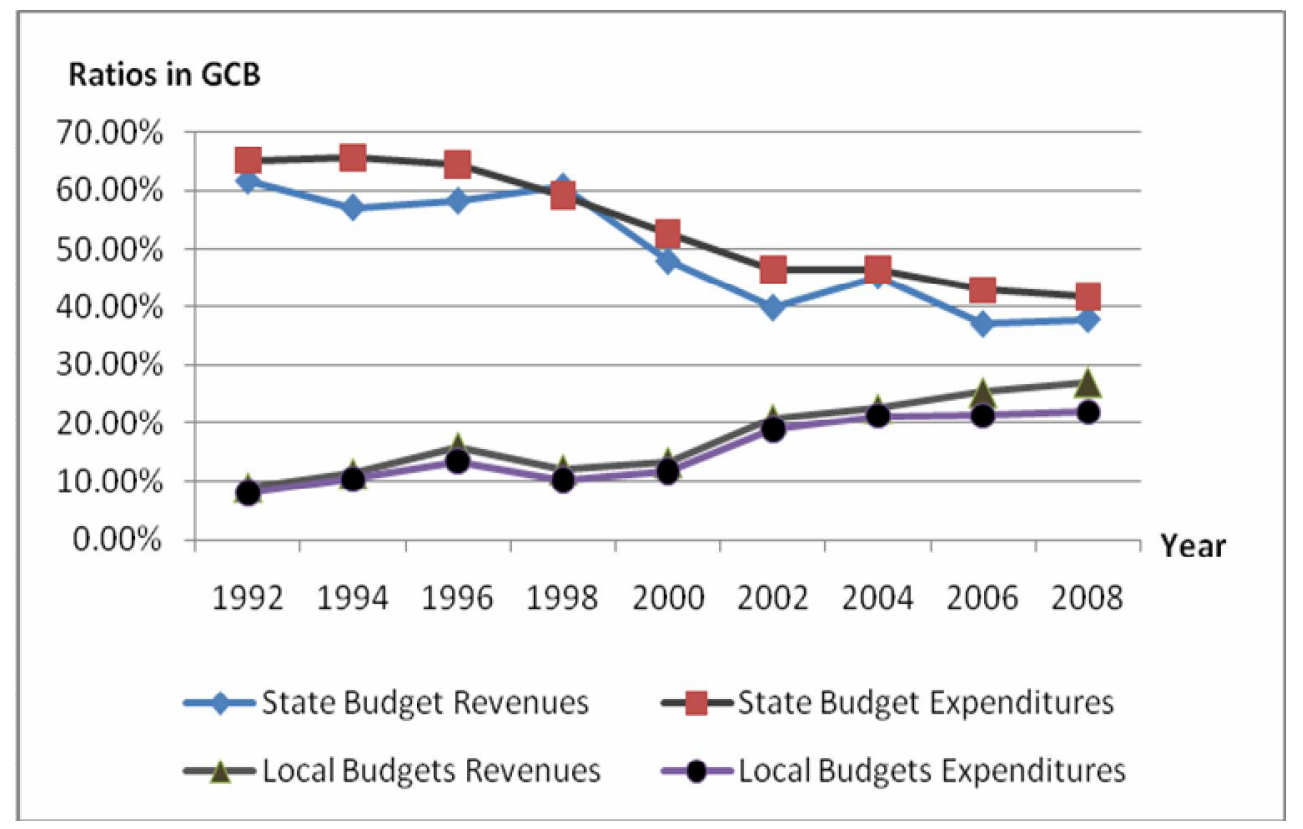

Fig. no. 1 - The Evolution of the Incomes and Expenditures of the State Budget and of Local Budgets in Romania (1992-2008) 
In this figure one may notice the evolution towards convergence of the shares of the incomes and expenses of the state budget and of the local budgets in the total incomes and expenses of the general consolidated budget (GCB), as an effect of the reconsideration of assigning the competences of public authorities on the two governing levels. At the same time, it can also be noted that the shares of the incomes and expenses of these budgetary components are closer in the case of local budgets, in their case the principle of budget balancing being expressly provided, as opposed to the case of the state budget, where differences are rather big.

Although the need to ensure the sufficiency of the financial resources of local budgets was always invoked as a direction for the administrative and financial reform, during the analyzed time period the transfer of competences to the local authorities was always subject to a certain lack of synchronization with the transfer (surrender) of the corresponding income sources, which maintained the financial dependence of local authorities (budgets) on the central ones at a rather high level for several years in a row. From this perspective, the evolution of the transfers from the state budget to local budgets is representative for the analyzed time period (1992-2008), the data being included in the following table:

Table no. 1

The Size and Share of the Transfers to the Local Level from the State Budget in Romania, during 1992-2008

\begin{tabular}{|l|r|r|r|r|r|r|r|r|r|}
\hline Year & $\mathbf{1 9 9 2}$ & $\mathbf{1 9 9 4}$ & $\mathbf{1 9 9 6}$ & $\mathbf{1 9 9 8}$ & $\mathbf{2 0 0 0}$ & $\mathbf{2 0 0 2}$ & $\mathbf{2 0 0 4}$ & $\mathbf{2 0 0 6}$ & $\mathbf{2 0 0 8}$ \\
\hline $\begin{array}{l}\text { Revenues } \\
\text { from income } \\
\text { tax (mil. lei) }\end{array}$ & 0,00 & 66,81 & 197,26 & 499,80 & $1.743,50$ & $3.907,00$ & $6.633,70$ & $7.550,30$ & $14.242,00$ \\
\hline $\begin{array}{l}\text { Revenues } \\
\text { from VAT } \\
\text { (mil. lei) }\end{array}$ & 0,00 & 0,00 & 0,00 & 0,00 & 0,00 & $3.185,10$ & $5.274,00$ & $14.539,00$ & $18.634,30$ \\
\hline $\begin{array}{l}\text { Special } \\
\text { destination } \\
\text { revenues } \\
\text { (mil. lei) }\end{array}$ & 0,00 & 0,00 & 0,00 & 0,00 & 352,30 & 432,70 & 0,00 & 0,00 & 0,00 \\
\hline $\begin{array}{l}\text { Subsidies } \\
\text { (mil. lei) }\end{array}$ & 16,80 & 76,25 & 184,85 & 505,45 & 285,20 & 117,40 & 920,20 & 923,40 & $4.221,50$ \\
\hline $\begin{array}{l}\text { Share of } \\
\text { transfers in } \\
\text { local budgets } \\
\text { revenues (\%) }\end{array}$ & 84,13 & 80,95 & 76,44 & 74,72 & 71,19 & 81,97 & 80,40 & 83,05 & 85,03 \\
\hline
\end{tabular}

Source: Romanian National Institute of Statistics, $\underline{w w w . i n s s e . r o}$

As one may note from the data included in the table, the sums and quotas distributed from some incomes of the state budget to the local level experienced, during the 1992-2008 period, a general upward evolution, especially in the case of the sums distributed from the VAT. As the table shows, until the year 1998, the main transferred financial resources were the subsidies due to Law no. 27/1994 regarding local taxes. The law mainly established property taxes, which brought revenues lower than the local expenditures. In nominal values, these subsidies have recorded substantial growth, especially in 2008, excepting for years 2000 and 2002. As the transfer of administrative competences was intensified, this disproportion became even more obvious. Even thought, Law no. 189/1998 regarding local finances was intended to ensure enough revenues to local budgets, the situation lingered, revenues from income tax being transferred in larger amounts. AS the table shows, the transferred revenues have grown in nominal terms, more than 200 times. At the same time, the state budget had transferred to local ones substantial revenues from VAT. In this case, the growth of transferred resources was of $600 \%$. Starting with 2003, revenues from income tax were 
considered "local own incomes". It is important to note first that most of these incomes are unconditional transfers, meant for balancing, which must be treated as own incomes. At the same time, we must note that these transfers represent, in some cases (VAT and income tax), over $80 \%$ of the state budget incomes, the amount remaining at its disposal being rather small. In these conditions, we believe that in order to simplify and make public budgetary relationships more efficient, it would be more appropriate that the tax on certain income sources with local repercussion (e.g.: the tax on income from wages) be entirely conceded to local communities, because it seems natural that the members of the community that perform productive activities at this level and bear these tax contributions enjoy the public utilities created at their expense.

In the current situation, an issue arises from the point of view of the transfer of the balancing sums and the fact that our legislator found it appropriate, in distributing these funds, to provide the possibility that a certain percentage may not be distributed according to objective criteria (number of inhabitants, length of road network etc.), but based on the decision of the decision-making county authority, for the local investment projects, which often creates great dissatisfaction, as distribution based on political criteria is invoked.

Starting with 2003, the distributed quotas from the income tax have been included in the category of own incomes of local budgets, context in which it is necessary to provide certain specifications regarding the financial dependence of local authorities (budgets) on the central ones. Although, in practice, it is sometimes said that these incomes (transferred from the state budget) are not actual "own" incomes of the local budgets, we believe that their constitution method (based largely on pre-set percentages, ratios and criteria) justifies such an approach.

This aspect is important because, in order to characterize the degree of financial autonomy/ dependence of local public authorities on central ones, the calculation of the ratio between the own incomes and total incomes of local communities, as well as of the ratio between their own incomes and expenses, is also relevant. In the first case, the resulted percentage reflects the financial autonomy of local communities (being the reverse of the degree of financial dependence), and in the second case the result reflects the self-financing ability of local administrations. In the following table are included the data corresponding to the time period from 1992-2008:

Table no. 2

The Ratio between the Own Incomes and the Total Incomes/Expenses of the Local Public Authorities in Romania during 1992-2008

\begin{tabular}{|l|l|l|l|l|l|l|l|l|l|}
\hline Year & $\mathbf{1 9 9 2}$ & $\mathbf{1 9 9 4}$ & $\mathbf{1 9 9 6}$ & $\mathbf{1 9 9 8}$ & $\mathbf{2 0 0 0}$ & $\mathbf{2 0 0 2}$ & $\mathbf{2 0 0 4}$ & $\mathbf{2 0 0 6}$ & $\mathbf{2 0 0 8}$ \\
\hline $\begin{array}{l}\text { Local } \\
\text { Budgets } \\
\begin{array}{l}\text { Revenues } \\
\text { (Total) }\end{array}\end{array}$ & 19,97 & 176,72 & 499,85 & $1.345,42$ & $3.344,5$ & $9.322,8$ & $15.955,8$ & $27.708,6$ & $43.629,1$ \\
\hline $\begin{array}{l}\text { Local } \\
\text { Budgets } \\
\text { Expenditures }\end{array}$ & 19,94 & 173,51 & 495,52 & $1.338,15$ & $3.321,7$ & $9.258,8$ & $15.540,7$ & $25.392,8$ & $42.210,2$ \\
\hline $\begin{array}{l}\text { Own Local } \\
\text { Budgets } \\
\text { Revenues }\end{array}$ & 3,16 & 33,50 & 113,04 & 332,82 & 861,2 & $1.620,7$ & $9.709,7$ & $12.152,1$ & $20.587,7$ \\
\hline $\begin{array}{l}\text { Financial } \\
\text { Autonomy } \\
\text { Degree }\end{array}$ & 15,82 & 18,96 & 22,61 & 24,74 & 25,75 & 17,38 & 60,85 & 43,86 & 47,19 \\
\hline $\begin{array}{l}\text { Self- } \\
\text { financing } \\
\text { capacity (\%) }\end{array}$ & 15,85 & 19,31 & 22,81 & 24,87 & 25,93 & 17,50 & 62,48 & 47,86 & 48,77 \\
\hline
\end{tabular}

Source: Romanian National Institute of Statistics, $\underline{\text { www.insse.ro }}$ 
The data processed and synthesized in the table show the fact that during 1992-2002, the financial dependence of local authorities on the central ones was high, the degree of financial autonomy not exceeding $25.75 \%$ (the minimum recorded value being $15.82 \%$ in 1992), and the selffinancing ability had, in its turn, quite low values, ranging between $15.85 \%$ in 1992 and $25.93 \%$ in 2000. However, once the category of own incomes is reconsidered, the degree of financial autonomy increased in 2004 to $60.85 \%$ and the self-financing ability, to $62.48 \%$. During the following years, these values decreased again, while the decentralization process continued, the allotted sums always being for the first year distinctively included in the appendix to the budgetary law. We must also note, from the table above, "the sensitive points" of the evolution of these indicators, represented by the growth in 1996 and 2000 as a result of adopting certain regulations regarding local finances, which do not confirm, however, through the recorded values, the results that the legislative modifications envisaged.

Although these evolutions may be explained without any reserve through the need for financial support from the state of the administrative decentralization process, the transfer of certain competences, previously exercised by the central authorities, to certain local authorities, having to be accompanied by the transfer of covering resources, the essential issue that arises does not concern the level or the evolution of the sums (distributed quotas or sums, transfers, subsidies, etc.) in themselves, but their method of establishment, their foundation, essentially from the perspective of the rationality of the interrelationships manifested between the components of the public budgetary system. In the current Romanian practice, the transferred sums (from the income tax) are based on legally pre-set quotas, distributed to local communities according to balancing formulas which include the financial capacity, the number of inhabitants etc. However, the current regulation highlights only the distribution technique and criteria of the sums meant for balancing, leaving on the second place the establishment method of their amount at the central level. As a result, it is however necessary to set certain clear criteria for the process of establishing the amount of the sums which will be transferred from the state budget.

The use of minimum cost standards and of quality standards for the provision of public services to the population must be the main rational work references. Thus, starting from the experience of some countries in which this practice has become habitual (Holland, the United Kingdom), we believe that it is absolutely necessary to draw up such standards and to annually determine, on an individual basis, according to each type of administrative-territorial unit and the actual circumstance, the maximum admissible level of the operation expenses. Although it may be invoked that setting such standards is difficult, to say the least, we note that the states concerned drew up specific methodologies, which are not only an adequate reference, but also a reference tested in practice in this regard. At the same time, comparing the results achieved based on its own construction, starting from the references offered by these methodologies, to other states (comparable, for example, due to the size of the gross domestic product per capita but not only) and making the necessary corrections required by the national specific characteristics (the wages level, the number of beneficiaries, the exchange rate, the specific weight of the responsibilities of the institution, etc.) may be a basis for the well-balanced sizing of these standards. An important aspect that should be taken into account would be the individualization according to the types of administrative-territorial communities, bearing in mind not only their specific characteristics by level (for example, the differences between the public services offered at rural level and at urban level) but also the characteristics at each level (e.g.: the city of Bucharest compared to the other cities), including adequate correction indices.

Another debatable aspect to be remarked in relation to the method of establishing the transfers, the quotas and the sums distributed from the state budget is related to the moment in which they are set. Naturally, the amount of these sums should be determined based on the "real" deficits of local budgets, based on judging the viability of the local authorities' projects. In practice, the Government approval only concerns the new investment objectives financed from external loans 
and, as a supplement, from transfers from the state budget and other sources, as well as the ones entirely or as a supplement financed from external loans contracted or guaranteed by the state, whatever their value, without concerning the investment objectives whose financing is ensured entirely or as a supplement from local budgets or the ones financed from domestic or external loans, directly, or guaranteed by the authorities of the local public administration, which are approved by the decision-making authorities. The work method is undoubtedly favourable to exercising local autonomy, but it may have as an effect an over-indebtedness of local authorities for financing investment objectives "evading" the Government approval, with direct effects on the functionality of the public budgetary system in its entirety.

From another perspective, the phasing of the budgetary process partially reverses the normal course of a budgetary projection, setting that the Finance Ministry first sends the framework letter to the local authorities by which it sets the limits of the distributed sums, based on which local agents will draw up budget projects. In our opinion, we think that the rationality of the budgetary projection supposes that it must have at its basis, as starting point, the sizing of actual local needs, according to which it must identify financial covering sources, and not certain incomes that it must distribute because they exist.

From another point of view, the lack of a strict and legally required technique of establishing the size of the quotas distributed from the income tax due to the state budget, to the local budgets is confirmed by the legal provision in art. 32 in the law regarding local public finances, according to which "in special situations, under the law regarding the state budget, the quotas distributed from the income tax may be increased". Judging per a contrario, the existence of adequate criteria, limits, techniques and procedures of establishing the amount of the distributed quotas would make this legal specification completely unnecessary and even contrary to the existence of a basis of establishing the sums. On the other hand, we believed it reasonable that the legal text should include a reverse specification, in the sense that in special situations, it should be possible to decrease the quotas, as it has actually happened in 2010.

Compared to the previous aspects, we consider that the method of determining the amount of the transfers, the sums and the quotas distributed from certain incomes of the state budget must be reconsidered, imposing as compulsory an ex ante evaluation of the demands of the main credit orderers of local budgets.

Overall, the transfer of sums made from the state budget to other budgetary components in order to balance them, lead to a reflection, in fact, in the central budget, of the actual negative balances of these budgets (considered as differences between own incomes and expenses to be made), and to the deficit being partially "covered", in the general consolidated budget, by the surplus of other budgetary components (special funds). In brief, during the analyzed period, the deficit experienced by the two budgetary components (the state budget and the general consolidated budget) was chronic, as it may be noticed in the following figure: 


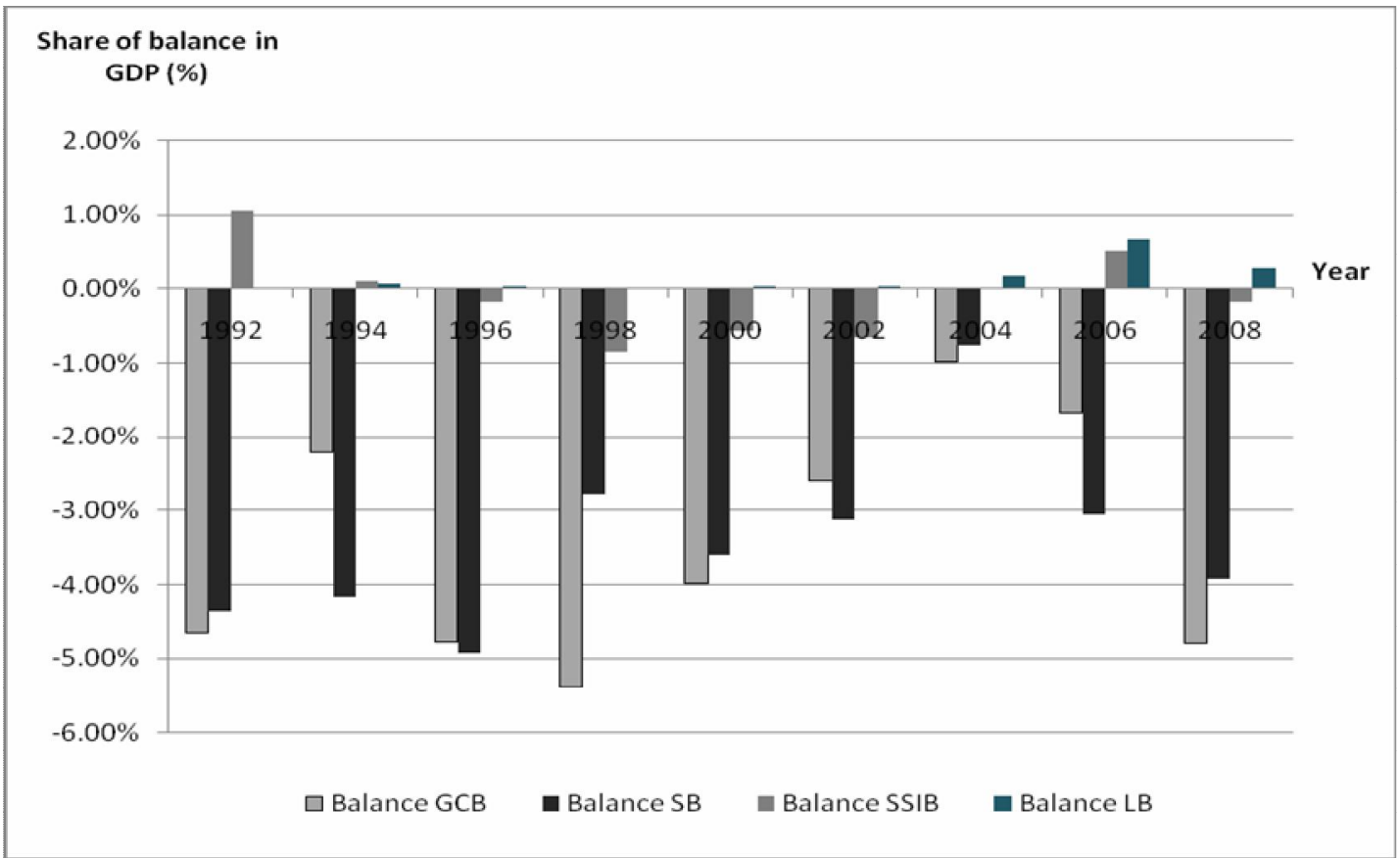

Fig. no. 2 - The Evolution of the Balances of the Main Components of the Public Budgetary System in Romania, during the 1992-2008 Period

In the figure, we note that the general consolidated budget (GCB) experienced a chronic deficit in the analyzed period, with an improvement period between 1998 and 2005, after which the tendency shifted again towards a worsening of the deficit, in 2008 reaching a condition close to the one in the first years of transition (1992). This evolution is due to the creation beginning with 1998 of a new legislative framework of local public finances, which allowed the balancing of local budgets and even the accumulation of surpluses which partially compensated the deficit of the general consolidated budget generated by the deficit condition of the state budget or of some of the special funds. The deficit experienced several years in a row by the state budget has its source in the transfer of balancing sums to other components of the public budgetary system. Essentially, the deficit of the state budget resembles from this perspective the constitution of the deficit of the general consolidated budget, representing in these conditions a summary of the imbalances experienced by the other components of the public budgetary system, for the coverage of which the balancing sums (subsidies, allowances and transfers) were granted. The reflection of the actual deficits of local budgets in the state budget, namely in the general consolidated budget, by covering them based on the transferred sums, does not solve the essential problems of the soundness of public finances, namely of the budgetary system, and new reconsiderations of the interrelationships between public budgets are still necessary.

\section{Conclusions}

In the analyzed period, the Romanian public budgetary system benefited from various improvements, which were not enough to maintain an adequate, balanced condition of local public budgets, new changes being made in 2010. As a first conclusion, we believe that it is necessary to reduce the relative importance of the equalization system in the budgetary system. In this context, it is necessary to assign more substantial income sources to local budgets, creating a direct link between the local fiscal effort and the expenses made at this level, in order to increase local authorities responsibility. Also, the rearrangement of the interrelationships between the state budget and local budgets supposes that the future decisions regarding the administrative decentralization 
should be preceded by the distinction of the financing sources of the actions involved, otherwise the effects being contrary to the expected ones. In actuality, the decentralization of hospitals operated this year, in the conditions in which the associated financing sources have not been specified, raises questions. On an extended plane, it is necessary to set up adequate local financial performance indicators, correlated, through the degree of implementation, to the size of the transfers from other public budgets, so as to ensure the support for transferring responsibility to local agents. In this context, the creation of a shared interest mechanism meant to attract non-refundable financial assistance, which could be based on using matching-grant transfers in which the participation share be gradually differentiated according to the attracted resources, may be, in the current conditions, a favourable premise for supporting local budgets and the development of local communities in general.

Taking into account the evolutions experienced by other European budgetary systems, we consider that the tendency that has taken shape in the last years of administrative-territorial concentration as a support for the consolidation of local budgets and focusing of public budgets, should be accepted in Romania, creating a realistic support for the simplification of the public budgetary system and the interrelationships between the central component and the local ones, with direct effects on its functionality.

\section{References}

1. Adam, F., Ferrand, O., Rioux, R., 2006. Finances publiques, Dalloz-Sirey, Paris

2. Boadway, R., Shah, A., 2009. Fiscal Federalism - Principles and Practice of Multiorder Governance, Cambridge University Press, New York

3. McLure, Ch., Vazquez, Martinez J., The Assignment of Revenues and Expenditures in Intergovernmental Fiscal Relations, available on-line at http://www1.worldbank.org/ publicsector/decentralization/

4. Oates, W. E., 1999. An Essay of Fiscal Federalism, available on-line at http://www.jstor.org/pss/2564874

5. Onofrei, M., 2007. Administrație publică. Fundamente ştiințifice şi bune practici, "Al. I. Cuza" Publishing House, Iaşi

6. Moşteanu, T., (coord), 2008. Buget şi trezorerie publică, Universitară Publishing House,, Bucureşti

7. Musgrave, R., Musgrave, P., 1989. Public Finance in Theory and Practice, McGraw Hill, New York

8. Shah, A.,(edit.), 2008. Macro Federalism and Local Finance, World Bank

9. Văcărel, I., (coord.), 2006. Finanțe publice, Didactică şi Pedagogică Publishing House,, Bucureşti

10. Statistical Yearbook of Romania, 2009 